\title{
Ten Minutes for School Environments: Strengthening Character Education Policy in DIY
}

\author{
Sa'dun Akbar \\ Faculty of Education \\ Malang State University \\ Malang, Indonesia \\ sakdun.akbar.fip@um.ac.id
}

\author{
Lenita Puspitasari \\ Graduate School \\ Malang State University \\ Malang, Indonesia \\ lenita.puspitasari@gmail.com
}

\begin{abstract}
Character education practices in various schools are considered still not alive and strong. The Revitalization of Character Education and Strengthening Character Education Movement is an effort to revive and strengthen educational practices that are meaningful to build good character. Among the policies of the Ministry of Education and Culture, the Yogyakarta Regional Area is Ten Minutes for the School Environment (SMUTLIS). The SMUTLIS policy is a very sympathetic policy because of the overwhelming response from schools and proven to be able to develop good character throughout the school community.
\end{abstract}

\section{Keywords—strengthening, character education, SMUTLIS}

\section{INTRODUCTION}

Character education has been implemented since the existence of education because among the goals of education is to make the character good. The problem is that in the last fifteen years it has been recognized that the practice of education is less meaningful as character education. The symptoms are the tendency of over cognitive education practices and over behavioristic education practices. This tendency is characterized by teacher-centered learning practices, learning practices that do not activate students, dependence on high textbooks and others.

Curriculum changes from the curriculum that tends to base on the philosophy of cognitivism with Content-Based Curriculum (Curriculum 1984 and Curriculum 1994), developed into a curriculum that tends to be based on the philosophy of Constructivism with Competence Based Curriculum (KBK curriculum-early 2000s, Curriculum 2004had not yet been enforced, Curriculum KTSP-2006, and the initial 2013 Curriculum and the revised 2013 National Curriculum) are efforts to prioritize character education.

Another phenomenon that triggers the need for Strengthening Character Education (PPK) is the existence of symptoms of bad character, and the practice of education and learning that lack education in character. PPK is an effort to strengthen the practice of education and learning in the context of developing good character in the education environment. The character that needs to be developed through PPK is the character of all large school residentsboth the characters of students, teachers, administrative staff, school guards, and other school community members.

Several studies conducted by researchers in various schools found the fact that bad characters sometimes occur in students, teachers and lecturers, administrative staff, and community members of other education units. Among the bad character phenomena that are often encountered are caring, responsibility, cooperation, cleanliness, and beauty. This phenomenon occurs evenly in most more education units in schools where students come from 'the have' family who is all-sufficient and tends to be spoiled by their parents.

The Yogyakarta Ministry of Education and Culture issued a Ten Minute policy for the School Environment (SMUTLIS) to strengthen the practice of character education. This SMUTLIS is able to make school residents care more about the environment, responsibility, cooperation, and the school environment to be good.

\section{METHOD}

This study uses a descriptive qualitative approach. The background of this study is at Bhayangkara Elementary School in Yogyakarta. Data were collected through observation, interviews, and focusing group discussions. Observation is used to collect data about the physical situation of the school and the various symptoms of the visible character. Interviews are used to collect data about the development and application of the SMUTLIS policy in schools and to reveal the strength of the character of school citizens. Focused discussions are used to confirm the SMUTLIS policy and the various impacts it causes. The data is analyzed qualitatively, analyzed by linking various symptoms related to SMUTLIS with the strengthening of educational practices and the strengthening of visible characters so that some research findings can be described.

With the basis of the findings of the study, an analysis was carried out that linked various symptoms of the implementation of SMUTLIS with the symptoms of strengthening the character of school citizens, both for students, teachers, and school community members. The analysis produces propositions that describe the role of the SMUTLIS policy in strengthening the character of large citizens of the education unit.

\section{RESULT}

In schools within the DIY Ministry of Education and Culture, the SMUTLIS is implemented, a DIY Ministry of Education and Culture policy in the context of character education. SMUTLIS is the policy of the DIY Ministry of Education and Culture that applies the Ten Minutes before the lesson, starting with all the large school residents (students, teachers, administrative staff, janitors) and other school community members working together to clean and maintain the school environment. Care for cleaning and caring for the school environment was carried out ten minutes before 07.00 before the lesson began.

The implementation of this SMUTLIS policy has an impact on almost every school in Yogyakarta deliberately arranging the physical environment around the school as a 
source, media, and vehicle for learning. In SD Bhayangkara Yogyakarta for example, the background of this research is to organize the school's physical environment as a source, media, as well as a vehicle for learning character values. Physically each class is given the trust to make a classroom garden. Each class has a garden in areas that are divided by class. Schools use the walls that surround the school with plants arranged vertically attached to the walls that surround the schoolyard. All around the wall including in front of certain classes stretched mini parks whose development and maintenance were the responsibility of each class.

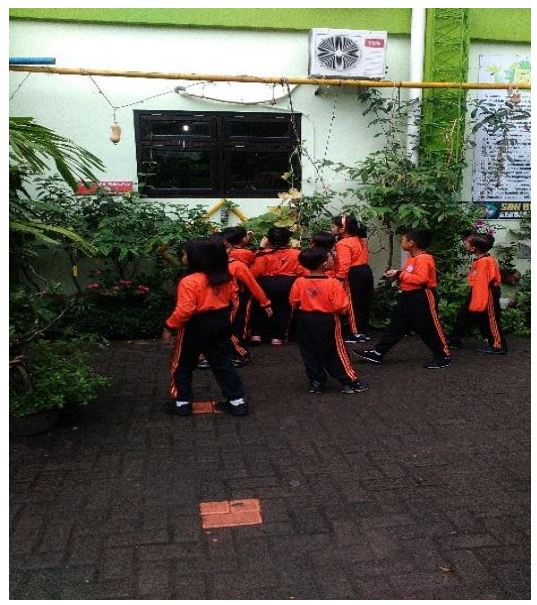

Fig. 1. SMUTLIS activities at SD Bhayangkara DIY

In ten minutes before the students entered the classroom, all the school community members worked together to sweep the floor, wiping the glass, turning on the dust stuck to the table on the wall.

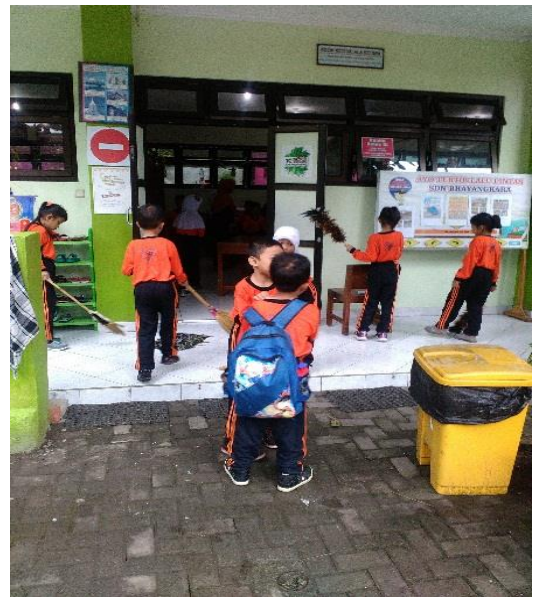

Fig. 2. SMUTLIS activities at SD Bhayangkara DIY

There were also teachers, students, school cleaners who watered the plants, weeded the grass between the plants, picked dried leaves attached to the school garden. They seem to work spontaneously without being told because it seems that this has become a habit in school.

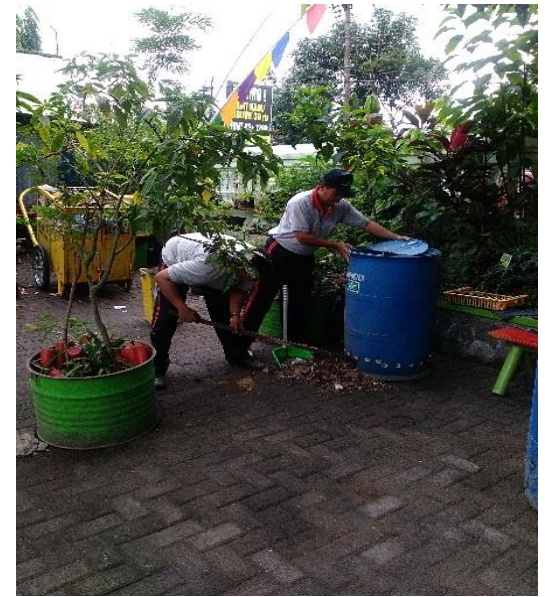

Fig. 3. SMUTLIS activity with the teacher

This phenomenon illustrates that school policy, at SMUTLIS is able to develop habits and attitudes of caring for the environment, building collaboration among all major citizens of the school, responsibility, independence. SMUTLIS can also bring feelings of love to plants as God's creation.

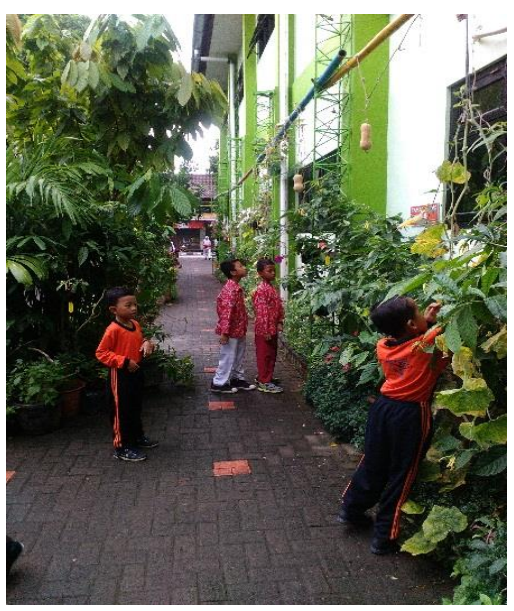

Fig. 4. SMUTLIS activity with the teacher

\section{DISSCUSION}

The SMUTLIS policy is a very good policy for character education. SMUTLIS is able to move schools to organize the school's physical environment by creating school gardens and gardens divided by class. SMUTLIS has an impact on the school environment being beautiful and being a clean, beautiful and comfortable environment for learning. Character education is not a slogan or a course, but a value that is intentionally instilled every day in the school environment [1]. The school environment itself has a function as a vehicle for character education practices both inside and outside the school. Likewise, with the SMUTLIS activities at school, it was designed and implemented with a view to strengthening the value of environmental care for students in the school environment both in the classroom and outside the classroom.

The division of tasks and responsibilities of caring for and preserving the environment the occurrence of social structuring occurs in schools in the context of character education. With the division of class-based environmental 
care tasks, students and teachers in each class can work together in teams, competing positively between classes by sharing each other's parks and gardens. Can develop pride in being a class member and a sense of responsibility and care for caring for the park and the school environment. The simultaneous collaboration in ten minutes can be felt by the attitude of togetherness between teachers and students so that it can shorten the distance between them. Teachers and students can interact closely. The closeness of students with these teachers will have implications for increasing mutual trust between them and in turn education and learning become more effective in a pleasant atmosphere.

The results of Akbar's research conducted at Kranggan 1 Elementary School in Mojokerto, Ngunut 6 Public Elementary School in Tulungagung, and at Sedatigede Sidoarjo Elementary School showed that cooperative learning practices were able to develop cooperation and create pride in the team [2]. At SD Sedati Gede Sidoarjo, for example, each class has mini-parks in front of each class. Through this mini-park, every child can take care of plants in their respective parks. Through this park can be developed a sense of responsibility, cooperation, care, and pride as class members. Cooperative learning is a very good learning for character education.

The constructivist learning activities need to be supported by the design and concept of learning that is oriented towards the collaborative learning competencies of students [3]. Because the participation and involvement of students is an important characteristic of constructivist learning. Teachers as facilitators need to facilitate students in the activity of submitting problem statements or challenging projects. In connection with the SMUTLIS activities that are cultivated in DIY, this activity is intended to build and shape the learning experience of students with cooperative education practices between students, teachers and all school residents.

Theoretically, someone is in a field or living space. In the living space, there are observed phenomena and internalized phenomena. Structuring the physical situation of the school park is an observed phenomenon. Social interaction between school residents in SMUTLIS is also an observed phenomenon. From the observed phenomenon will be an internalized phenomenon. It is a perception (perception) that the observed phenomenon determines the character. So structuring the physical and social situation in an educational environment is something very basic.

The SMUTLIS policy can also make students more creative. The creativity of these students can be seen from the appearance of a garden model that is very unique in terms of garden layout and arrangement of plant types in class parks. The results of interviews with teachers stated that these classroom parks were also used as a vehicle that could be used for the implementation of the scientific approach to learning in related subjects. Students can observe, question the situation, connect various physical symptoms that appear in class parks, identify problems and think about solving problems in the park. So, the presence of class parks and the use of the park by the teacher as a learning resource can make participants more critical, creative, innovative, and innovative. Whether you realize it or not, 21st-century skills can be presented and internalized character values in students through the SMUTLIS policy.
Students who are studying at school are currently living in a fast-paced world of change in a situation of internet revolution, digital revolution, scientific revolution and other revolutions, where they live in the world of VUCA [4]. At this time and after graduation they will live in an uncertain situation. Characteristics of a resilient personality are able to face various challenges and challenges of life, can survive, and can live (active role) in a life whose situation is uncertain are those who are critical, creative, productive, communicative and collaborative. The SMUTLIS policy supports the growth of critical, creative, productive, collaborative and communicative generations.

This SMUTLIS policy is associated with the philosophy of character education (education adapt) $\mathrm{Ki}$ Hadjar Dewantoro can trigger educational practices that apply the philosophy and principles of Ngerti, Ngroso, Nglakoni [5]. Through the responsibility of caring for and preserving the school environment, students' knowledge becomes broader, by working to care for the school environment can bring love to various kinds of plants that are cared for, by working on garden maintenance can also improve the skills needed in everyday life.

The results of the study on the application of the Triprakoro learning model that applies the principles of Ngerti, Ngroso, and Nglakoni show that the model can activate students, can make them active, they can construct their own knowledge [6,7]. The model is also effective in achieving targeted learning goals, especially regarding compliance with regulations and cooperation.

With SMUTLIS, school residents can do daily reflection activities on the state of the park. Reflection is an activity to rethink the state of the park. They can see firsthand what is not good the various plants in the garden, what else needs to be repaired and continue to carry out the garden maintenance work in the next cycle. To accelerate the process of internalization of values a learning process is needed that involves Understanding, Action, and Reflection [8]. The reflection process that is carried out in the learning process allows students to construct new knowledge from the experience of caring for the park, for example.

So, SMUTLIS can develop constructive and active learning practices. Observations and maintenance of school parks can spur activity: thinking, speaking and doing. This is supported by the opinion to find out the fact that moral education in Australian public schools is not taught entirely in learning activities, but moral values are taught to correspond between people one person or colleagues [9]. Activities that involve people or partners reflect the SMUTLIS activities held by DIY in order to develop the value of caring for the environment. Through SMUTLIS activities, constructivist learning can be done to activate students in exploring their knowledge. The constructivist learning emphasizes more on psychomotor aspects [10]. The position of the teacher in learning activities is to direct and control learning activities in accordance with the competencies achieved by students.

SMUTLIS can also create a joyful learning environment. When the child is pulling grass, picking dried leaves, watering the plants, wiping the glass and others they are happy to hear soft voices while singing songs, some running around, some watering while playing water, also playing duster to play. They can learn and work while playing. This 
is in line with opinion which states that Joyful Learning is a learning approach that involves feeling happy, happy, and comfortable from the parties in the learning process [11]. There is an attachment of love and affection between the teacher and students and between students, and the learning process will make each party try to give the best to please others. Teachers with zealous enthusiasm will seek the optimal lead class as it is most interesting, while participants with enthusiasm and competing actively take part in any activity. Thus, Fun Learning becomes a tool that makes teachers and students become like session-by-session lessons so that the results will be maximal.

\section{CONCLUSION}

Ten Minutes for School Environment (SMUTLIS) is a very sympathetic policy. Besides getting remarks from schools in Yogyakarta Special Region can also be a source of learning for students. With the SMUTLIS policy, schools transform their school environment into a beautiful and beautiful environment. In schools in DIY develop class parks that is the park which is the responsibility of the development and maintenance of each class.

The results showed that through the SMUTLIS Policy it was able to change the school environment that was rich in resources and learning media. SMUTLIS students can do real work in collaboration. This learning can train the attitude of responsibility, concern, cooperation, and other positive attitudes. SMUTLIS is able to mobilize school residents to care about the school environment. The principles of constructive, scientific, active, and orientation towards the integration of 21 st-century values (critical, creative, productive, cooperative, and communicative can be done well. Life-based learning can also be done through this SMUTLIS movement.

\section{REFERENCES}

[1] Agboola, and Tsai, "Bring Character Education into Classroom". European Journal of Educational Research, 2012.

[2] Akbar. Sa'dun, "Best Practise Pendidikan Karakter". Malang: Penerbit dan Percetakan UM, 2015.

[3] Andrea. Scheer, "Transforming Constructivist Learning into Action: Design Thinking in education". Germany: Design and Technology Education "An International Journal 17.3, vol. 10, 2012.

[4] Universitas Negeri Malang, "Naskah Akademik: Learning Innovation to Enhance Professional and Capability Development". Malang: I-CLIR Indonesian Consortium for Learning Innovation Research Universitas Negeri Malang, 2017.

[5] Dewantoro. K H, "Bagian I: PENDIDIKAN". Yogyakarta: Yayasan Taman Siswa, 1962.

[6] Akbar. Sa'dun, "Pendidikan Karakter melalui Pembelajaran di Kelas". Jurnal Penelitian Dan Pendidikan IPS, Juni Eds, 2012.

[7] Akbar. Sa'dun, "Model Triprakoro untuk Pengembangan Nilai Kepatuhan". JURNAL ILMU PENDIDIKAN, vol. 19, 1, Juni 2013.

[8] Bohlin. Caren, "Building Character in School: Resource Guide". Sanfransisco: Jossey Bass, 2001.

[9] Aplin. Graeme, "Heritage As Exemplar: A Pedagogical Role For Heritage Studies in Values Education". Springer Science \& Business Media, LLC, 375, 2007.

[10] Loyens. Sofie M M, and Gijbels. David, "Understanding The Effects Of Constructivist Learning Environments: Introducing A MultiDirectional Approach”. Springer, 353, 2008.

[11] Anggoro. A, Sopandi. W, Sholehuddin. M, "Influence of Joyful Learning on Elementary Students' Attitudes Towards Science". Journal of Physics: Conference Series, vol. 812, 1 (5), 2017 